\title{
CONTRASTIVE ANALYSIS OF TENSE AND ASPECT IN ENGLISH AND INDONESIAN LANGUAGE
}

\author{
Bejo Sutrisno \\ Foreign Language High School (STIBA) IEC Jakarta, Indonesia \\ E-mail: bejo@stibaiec-jakarta.ac.id \\ Ana Ratna Sari \\ Foreign Language High School (STIBA) IEC \\ E-mail: ratnasari_ollo@ymail.com
}

\begin{abstract}
APA Citation: Sutrisno, B. \& Sari, A.R. (2018). Contrastive Analysis of Tense and Aspect in English and Indonesian Language. Journal of English Language and literature, 3(2), 107-119.doi:

10.2540/jell.v3i2.1846.
\end{abstract}

Received: 10-06-2018

Accepted: 15-08-2018

Published:01-09-2018

\begin{abstract}
This study aims to find out the comparison between English and Indonesian terms of finite verb form, tense and aspect. Language is the medium used by human to convey the contents of their minds. Language is also an object of study in educational institutions. Examples of interesting language to study and learn are English and Indonesian language, because each of them has distinct characteristics. The method used in this research is descriptive qualitative study. The result of this study shows that there are four groups of verb forms in English: simple, continuous, perfect and perfect continuous forms. Each of the groups has present, past, and future forms. This scientific paper will contribute empirical data from English and Indonesian language that will support contrastive analysis theory.
\end{abstract}

Keywords: contrastive analysis, aspects, tense

\section{INTRODUCTION}

Contrastive analysis is a study which concern with the comparison of two or more languages or subsystem of both languages. According to James (1980:3), contrastive analysis is a linguistic enterprise aimed at producing inverted twovalued typologies (a contrastive analysis is always concerned with a pair of languages), and founded on the assumption that languages can be compared. This research focuses on the tense and aspect in English and Indonesian Language. And the verb as the main form that is used to be analyzed. This research also concentrates on verbs in active voice, and the writer focuses on affirmative sentences.

Margareth Shertzer (1986:22) stated in her book The Elements of Grammar, 
a verb is a word that tells what the subject (noun, pronoun, or clause) does or what is done to it. The verb expresses action, mode of being, occurence, or condition, or should agree with its subject in person and number. Furthermore, verb also includes principal or main verb, which is the only verb in the sentence and not used with any auxiliary verb. As Curme (1935:69) wrote in his book, Parts of Speech and Accidence, an auxiliary verb is one that although originally independent, now only helps other verb, ... to form some of their parts.

From both definition above, the writer concludes that a verb is part of speech that conveys an action that inflected to encode tense, aspect, mood and voice. That is also agree with person, gender, and number of some of its arguments. And it is also includes the main verb which is only verb in the sentence and not used with auxiliary verb. The auxiliary verb itself is the helping verb, it is occurs before the main verb in the verb phrase.

In relation to the verb, there are also tense and aspect. Shertzer (1986: 27) stated that "tense is a distinctive form of a verb that expresses the time or action. Tense is indicated by inflection, that is, a change in the form of the verb itself (sing, sang, look, looked) or by the use of auxiliary verb forms (will sing, have looked)". In Indonesian language, it uses the term AKAN to indicate the future tense. And aspects, as wrote by Graham Tulloch (1990:7) in the book, English Grammar A Short Guide, is the feature of the verb which indicates whether the action is was or will be a completed one or a continuous one. In Indonesian language, the completed action is marked by the term SUDAH or
TELAH and the ongoing activity is marked by the term SEDANG. However, there is a distinction between TELAH and SUDAH, as the following example:

"Pak Lurah itu sudah mandi" (1994: 261) Sudah. In this case, TELAH is not appropriate.

The writer concludes that in relation to the verb, there are tenses and aspect. While tenses are the indicators of the time of action or state that is occurs with different forms. And aspect, is the form that concerns the manners which is the verbal action is whether completed or in progress.

In the book by Chaer (1994:260), Linguistik Umum, stated that tenses give information about actions or events that refer to the past, present, and future time. Some language mark the tenses morphemically, that is, they have special forms of verbs. English, for example, uses the suffix [-ed] to indicate past tense and $[\mathrm{BE}+\mathrm{V}$-ing $]$ to indicate continous tense. Some other languages mark the tense lexically. For instance, Indonesian language uses the terms SUDAH or TELAH, SEDANG and AKAN in front of the verbs to indicate the past, present and future tenses. In other words, tense indicates the action whether it is past, present, or future. Some language sign it morphemically, for the example, English uses the suffix [-ed] to denote the past tense and $[\mathrm{BE}+\mathrm{V}$-ing] to denote continous tense. Whereas some other languange such as Indonesian language mark the tense lexically, it uses the word SUDAH or TELAH, SEDANG and AKAN before the verbs to denote the past, present, and future tense. As stated the other book, Bahasa Indonesia Jurnalistik by R. Siregar (1987), it is said that an Indonesian sentence can use the term TELAH, AKAN, or SEDANG and the verb with time expression or only the verb with a time expression. If there is clear time expression, it is not necessary to use the 
term TELAH, SEDANG or AKAN, but if there is no time expression, one of these terms should be used with the verb in the sentence.

For example:

a. Dia sedang memasak hari ini.

This sentence uses both the term SEDANG and a time expression HARI INI.

b. Dia sedang memasak.

There is no time expression in the sentence; only SEDANG is used.

c. Dia memasak hari ini.

There is a time expression in the sentence, so the term SEDANG can be omitted.

In the book Belajar Bahasa Indonesia Tanpa Guru, Amin Singgih (1981) mentioned that Indonesian language does not have tense because there is no conjugation of verbs to express tense. However, there are tense-markers to express the time element of the action. For example:

1. Ahmad has eaten. Ahmad sudah makan.

The word SUDAH is the tense marker; it indicates that an action was done in the past.

2. Yesterday he went to Jakarta. Kemarin dia pergi ke Jakarta.

Here, the word KEMARIN is the tense marker; it indicates that an action was done in the past.

From the explanation above, the writer concludes Indonesian language use the form AKAN, TELAH, or SEDANG if there is no time expression in the sentence. But if the time expression in the sentence is clear, it is not needed to use the three forms. Indonesian language also does not have tense because there is no conjugation of verbs to express the tense.
Here, the researcher's use of tense is different from those authors. The researcher only refers to AKAN as the only tense (future tense) in Indonesian language and refers to SEDANG and TELAH or SUDAH as the aspects in Indonesian language. Dia memasak hari ini

In the book An Axiomatic Theory of Language with Application to English, it is said that verbs have past and nonpast forms. The nonpast form can be used in present, future and perfect tenses. The past form is used to describe an action at definite time in the past, habitual action in the past, no beginning or end of the duration, no forward reference to the point of reference, a comparison with present time (used to) and for all time in a few proverbial expressions (Pak, 1979).

In the book Longman Student Grammar of Spoken and Written English, it is stated that there are two kinds of verbs: (a) main verbs and (b) auxiliary verbs. Main verbs play a central role in clauses. They usually occur in the middle of a clause, and they are the most important element in the clause because they determine the other clause elements. While auxiliary verbs occur before a main verb and qualify the meaning of the main verb. (Biber, Conrad, Leech, 2002: 103).

In the book English Syntatic Structures: Functions \& Categories in Sentence Analysis, it states that auxiliary verbs cannot stand alone. Instead, the auxiliary verbs must be followed by principal verbs. An auxiliary verb, which is also called a helping verb, may be a modal auxiliary or a primary auxiliary. A modal auxiliary verb is always in finite form and it occurs in the first element of verb phrase. The primary auxiliary verb such as HAVE and BE have both finite and nonfinite forms and either may occur in initial and medial position in the verb phrase (Aarts, 1988:36). 


\begin{tabular}{|c|c|c|}
\hline Finite/initial & Non-finite/medial & Principal verb \\
\hline Will & have & Written \\
\hline Does & - & Write \\
\hline Has & Been & Writing \\
\hline
\end{tabular}

Table 1: verb phrase (Aarts, 1988:36)

The writer concludes that there are two kinds of verb class: main verb and auxiliary verb. Main verbs are the verbs that occur in the middle of the sentence. They are the most important elements in the clause because they decide the other clause elements. The main verbs may be the only verb in sentence. Whereas the auxiliary verbs are the verbs that occur before the main verb in the verb phrase, and they cannot stand alone. They also called the helping verbs and may be modal and primary. And the modal verbs always in finite form.

Contrastive analysis is a study which concern with the comparison of two or more languages or subsystem of both languages. According to James (1980:3), contrastive analysis is a linguistic enterprise aimed at producing inverted twovalued typologies (a contrastive analysis is always concerned with a pair of languages), and founded on the assumption that languages can be compared. In this case, the research goal is to find the differences and similarities between that two languages or the subsystem of them.

In other words, contrastive study is the study of a pair of languages with a view to draw out their structural differences and similarities. It was used in the field of Second Language Acquisition in around 1960s-1970s as a method of explaining the reason of some forms of a target language were more difficult to study than others.

In the book, Lingustic Across Cultures, Lado (1957:66, 76) stated that, there are some procedures in comparing two grammatical structure: general procedures and spesific procedures. The general procedures begin with analyzing the foreign language structure and then comparing it with native language structure. In analyzing each structure, it is necessary to consider whether there is a structure in the native language 1) signaled the same way, 2) having the same meaning, and 3) similarly distributed in the system of that language. Furthermore, in the spesific procedures, Lado added that there are some steps: locate the best structural description of the language involved, summarize in compact outline form all the structures, and the last, actual comparison of the two language structures pattern by pattern.

Different with Carl James (1980:6263) in his book, Contrastive Analysis, explained that there are two steps: 1) description of second language and first language; and 2) the comparison of the two. Furthermore, the descriptions need to be "parallel".

In other words, there are two steps in executing Contrastive Analysis, are those based upon a scientific description of the labguage to be learned, carefully compared with a parallel description of the native language. Parallel here means, one language is at least has related thing with another language those are compared.

Delahunty and Garvey (2010:122126) in the book the English language from sound to sense proposed that words are units composed of one or more morphemes; they are also the units of which phrases are composed. A morpheme is the smallest part of a word that has grammatical function or meaning. It is classified into four types: 
1. Bound or free morpheme, which can occur on its own as a word; it does not have to be attached to another morpheme, e.g. saw;

2. Root, is the basic form to which other morphemes are attached, e.g. $\{$ saw $\}$ is the root of sawer.

3. Derivational, is added to forms to create separate words: $\{-e r\}$ is a derivational suffix whose addition turns a verb into a noun, usually meaning the person or thing that performs the action denoted by the verb, e.g. $\{$ paint $\}+\{-e r\}$ creates painter

4. Inflectional, do not create separate words. They merely modify the word in which they occur in order to indicate grammatical properties such as plurality, as the $\{-\mathrm{s}\}$ of magazines does, or past tense, as the $\{$ ed $\}$ of babecued does."

From the both definitions above, the writer concluded that words are the combination of one or more morpheme and composed by phrases. While the morpheme is the smallest section of a word that has four classfications, bound or free, root, derivational, and inflectional morpheme. Bound or free morpheme is a morpheme that does not have to be unite to another morpheme; root is a base shape of word that other morphemes are united to; derivational is a morpheme that change the meaning of the base form; and inflectional is the contrary of the derivatonal morpheme, they change the word to signify the grammatical characteristics.

According to Boer in the book Basic Language Messages and Meaning (1982:228), he stated the verb tenses as the following:
"Every verb has three principal parts, or forms, from which all six tenses of a verb are derived. The present form is used alone to show the simple present. It is used with the auxiliarities shall or will to show the simple future. The past form is always used alone to show the simple past. The past participle is used with the auxilarities has or have, had, shall have, and will have to form the perfect tenses.

... the progressive forms of a verb show action continuing or continued over a period of time. There are six tenses of progressive forms in the active voice; each combines a tense form of to be with the present participle of the main verb. ..."

It is concluded that the three principal parts of the verb are present, past, and future forms. The six tenses are the simple present, simple past, simple future, present perfect, past perfect, and future perfect tenses. The six progressive tenses are present continous, past continous, future continous, present perfect continous, past perfect continous, and future perfect continous tenses.

Langacker (1972:207) in his book, Fundamentals of Linguistic Analysis discussed about the rule of agreement which relates to number, person, etc. of the noun form with verb form. For instance, the agreement between verb and the subject relates verb form with the number and person of its subject. In other words, a verb should agree with its subject, not with a noun placed between the verb and its subject.

\section{METHOD}


The method used in this research is descriptive qualitative study. Descriptive qualitative research is a research procedure which produces descriptive data in the form of written or oral words of people and of behavior which can be observed (Moleong, 1993 cited by Diyah B. Ernawati 2005). This research analyzed the data descriptively, in terms of the tense and aspect in English and Indonesian Language.

\section{RESULT AND DISCUSSION}

\section{Present simple}

The simple present form has the verb form BASE FORM of the verb for all subject or BASE FORM of the verb + [-s/es] only for third person singular subjects. So, the form in simple present form is a finite form because it changes according to person and number.

In the simple present form of English, as used in sentences 1 to 5 , the finite form is the main verb itself. Its equivalent in Indonesian language is also the main verb but in non-finite form.

There are no differences in the functions of the simple present form in Indonesian language and English, but here is the difference in the form of the verb in sentences number 6; English has conjugated forms of the verb but Indonesian language does not have it. Indonesian language can use either the base form of the verb, or [affix + verb].

As seen in sentences 6, English uses the copula $\mathrm{BE}, \mathrm{BE}$ in Indonesian language is ADALAH. But in these sentences one does not ADALAH. So, it is unacceptable if sentences in number 6 are like the following:

(1) *apartemen itu adalah bersih

(2) *saya adalah lebih baik sekarang, terima kasih

\section{Present perfect}

The present perfect form in English has the form [HAS / HAVE + V - EN].
The finite form in the present perfect form of English is HAS or HAVE which has an equivalent in Indonesian language: TELAH. The functions of present perfect form in English are accomplished by the verb form [TELAH + VERB] in Indonesian language, in general.

However, there are some sentences that do not use TELAH. In sentences with adverbs such as NEVER, RECENTLY, and JUST, one should not use the word TELAH. The following are unacceptable sentences in Indonesian language:

(3) *cuacanya telah sangat mengerikan.

(4) *Mort telah baru saja menyelesaikan pekerjaan rumahnya.

(5) *kami telah baru saja kembali dari liburan kami.

\section{Present Progressive}

The finite verb form in the present continous form is IS, AM or ARE. In Indonesian language, the equivalent form of the present continous is SEDANG and the verb.

Although Indonesian language uses the term SEDANG to mark the present continous form, not all sentences using the present continous form in English need SEDANG, when they are translated into Indonesian language. In the sentences number 1, SEDANG can be omitted as long as there is a present time expression in the sentence. Thus, these following sentences are also acceptable:

(6) Dia menghadiri sebuah pertemuan sekarang.

(7) Dia berjalan kaki ke sekolah sekarang.

In sentences 2, one even should omit the word SEDANG. Thus, the following sentences are unappropriate:

(8) *Saya sedang kuliah Geologi di Universitas Colorado. 


\section{(9) *Phyllis sedang tinggal dengan} orang tuanya.

In the sentences number 3 , in Indonesian language can make correct sentence with or without the term AKAN as long as there is future time expression. If one wants to use the term, SEDANG cannot be used in these sentences although in English one can use the present continous form to express the future. But in Indonesian language, AKAN should be used when the sentences reffer to the future actions.

Thus, these are unacceptable sentences (3) in Indonesia language:

(10) *dia sedang tiba besok.

\section{(11) *Saya sedang bermain} bulutangkis dengan Mathew besok.

\section{Present Perfect Progressive}

The form of present perfect continous form in English is [HAS / HAVE + BEEN
$+\mathrm{V}-\mathrm{ING}]$. The difference in function between present perfect form and present perfect continous form is that the later emphasizes the continous or progressive aspect of the action.

The finite form in the present perfect continous form of English is HAS or HAVE which has its equivalent in Indonesian language TELAH. In this form, English combines present form and two aspects (perfect and continous). In Indonesian language, this is not a case. Indonesian language only uses TELAH. The following sentences are unacceptable:

(12) * Kami telah sedang menunggu disini selama dua puluh menit.

(13) *Natasha telah sedang bermain piano sejak dia berusia empat tahun.

(14) * Kamu telah sedang memainkan komputer itu sejak pukul tujuh.

The aspect of Past Tense can be seen from the table below

\begin{tabular}{|c|c|c|c|}
\hline \multicolumn{4}{|c|}{ Aspect (tense) } \\
\hline Past simple & Past perfect & Past progressive & $\begin{array}{l}\text { Past perfect } \\
\text { progressive }\end{array}$ \\
\hline "tensed" & $\begin{array}{l}\text { "tensed" have + } \\
\text { past participle }\end{array}$ & $\begin{array}{l}\text { "tensed" be }+ \\
\text { present participle }\end{array}$ & $\begin{array}{l}\text { "tensed" have + } \\
\text { past participle or } \\
\text { be (been) + } \\
\text { present participle }\end{array}$ \\
\hline $\begin{array}{l}\text { 1. An action that } \\
\text { happened at a definite } \\
\text { time in the past } \\
\text { a.I attended a meeting } \\
\text { of that committee last } \\
\text { week. (sample 1: 63) }\end{array}$ & $\begin{array}{l}\text { 1. An action } \\
\text { completed in } \\
\text { the past prior to } \\
\text { some other past } \\
\text { event. } \\
\text { a. He had }\end{array}$ & $\begin{array}{l}\text { 1.An action in } \\
\text { progress at a } \\
\text { specific point of } \\
\text { time in the past. } \\
\text { a.He was walking } \\
\text { to school at }\end{array}$ & $\begin{array}{l}\text { 1. An action or } \\
\text { habit taking } \\
\text { place over a } \\
\text { period of time } \\
\text { in the past } \\
\text { prior to some }\end{array}$ \\
\hline $\begin{array}{l}\text { Saya menghadiri } \\
\text { pertemuan komite } \\
\text { pekan lalu. } \\
\text { b.He walked to school } \\
\text { yesterday. (sample } 1 \text { : } \\
63 \text { ) }\end{array}$ & 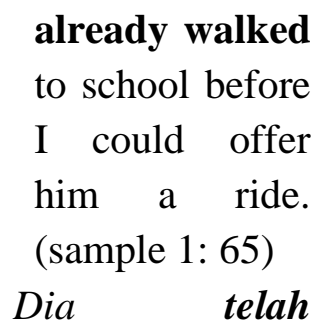 & $\begin{array}{l}08.30 \text { this } \\
\text { morning. } \\
\text { (sample 1: 63) } \\
\text { Dia berjalan kaki } \\
\text { ke sekolah pukul } \\
\text { 08.30 pagi ini. }\end{array}$ & $\begin{array}{l}\text { other past } \\
\text { event. } \\
\text { a.He had been } \\
\text { walking to } \\
\text { school before } \\
\text { his father }\end{array}$ \\
\hline
\end{tabular}




\begin{tabular}{|c|c|c|c|}
\hline $\begin{array}{l}\text { Dia berjalan kaki ke } \\
\text { sekolah kemarin. } \\
\text { 2.Habitual or repeated } \\
\text { action in the past. } \\
\text { a.Sam walked his dog } \\
\text { everyday last year. } \\
\text { (sample 1: 63) } \\
\text { Sam menjalankan } \\
\text { anjingnya setiap hari } \\
\text { tahun lalu. } \\
\text { c.It snowed almost } \\
\text { every weekend last } \\
\text { winter. (sample 1: 63) } \\
\text { Salju turun hampir } \\
\text { setiap akhir pekan } \\
\text { musim dingin lalu. } \\
\text { 3.Conditions or states in } \\
\text { the past } \\
\text { a.I was ill last week. } \\
\text { (sample 2: 18) } \\
\text { Saya sakit pekan lalu. } \\
\text { b. Those cakes were } \\
\text { nice. (sample 2: 18) } \\
\text { Kue itu lezat. }\end{array}$ & $\begin{array}{l}\text { berjalan kaki ke } \\
\text { sekolah sebelum } \\
\text { saya dapat } \\
\text { menawarkannya } \\
\text { tumpangan. } \\
\text { b. After the } \\
\text { guests had left, } \\
\text { I went to bed. } \\
\text { (sample 3: 39) } \\
\text { Setelah para } \\
\text { tamu pergi, } \\
\text { saya pergi } \\
\text { tidur. }\end{array}$ & $\begin{array}{l}\text { 2.An action that } \\
\text { was going on for } \\
\text { some time when } \\
\text { another action } \\
\text { happened. } \\
\text { a. Karen was } \\
\text { washing her hair } \\
\text { when the phone } \\
\text { rang. (sample 1: } \\
\text { 64) } \\
\text { Karen sedang } \\
\text { mencuci } \\
\text { rambutnya } \\
\text { ketika telepon } \\
\text { berdering. } \\
\text { b. While Alec was } \\
\text { traveling in } \\
\text { Europe, } \\
\text { house his } \\
\text { painted. (sample } \\
1: 64 \text { ) } \\
\text { Ketika } \\
\text { sedang Alec } \\
\text { melakukan } \\
\text { perjalanan di } \\
\text { Eropa, } \\
\text { rumahnya di cat. }\end{array}$ & $\begin{array}{l}\text { bought him a } \\
\text { bicycle. } \\
\text { (sample 1: 65) } \\
\text { Dia telah } \\
\text { berjalan kaki } \\
\text { ke sekolah } \\
\text { sebelum } \\
\text { ayahnya } \\
\text { membelikanny } \\
\text { a sebuah } \\
\text { sepeda. } \\
\text { b.Carol had } \\
\text { been working } \\
\text { very hard, so } \\
\text { her doctor told } \\
\text { her to take a } \\
\text { vacation. } \\
\text { (sample 1: } 65 \text { ) } \\
\text { Carol telah } \\
\text { bekerja sangat } \\
\text { keras, } \\
\text { sehingga } \\
\text { dokternya } \\
\text { memberitahu } \\
\text { dia untuk } \\
\text { berlibur. }\end{array}$ \\
\hline
\end{tabular}

Table 2. Past Tense

Sample 1. The Gramar Book An ESL / EFL Teacher's Course; Sample 2. Oxford Practice Grammar; Sample 3. Understanding and Using English Grammar

From the table 2 above, it can be described as the following.

1) Past Simple

In English simple past form, there are two types of verb: regular and irregular verb. For regular verbs, the simple past form is marked by adding [- $\mathrm{d}$ /-ed] to the base form of the verb. The simple past form has only one form for all subjects except for the verb $\mathrm{BE}$, which has two forms: 'was' and 'were'. 'was' is used with first person singular subject and third person singular subject while 'were' is used with the rest. For many irregular verbs, the simple past is made by a change in spelling and/or pronounciation of the base form of the verb. For a few verbs, there are no changes in forms. 
There are some differences in the forms in Indonesian language and English:

(a) The simple past form in English is a finite verb because the base form changes according to the tense and in the case of BE, also according to the person and number of the subject. In Indonesian language the equivalent of this English finite verb is a non-finite verb form because the base form of the verb is not conjugated in terms of tense.

(b) Here, Indonesian language does not use the term TELAH to indicate the past action, but the past action is indicated by using time expressions. So, these sentences are unacceptable in Indonesian language:

(15) *Saya telah menghadiri pertemuan komite pekan lalu.

(16) *Dia telah berjalan kaki ke sekolah kemarin.

(17) *Sam telah menjalankan anjingnya setiap hari tahun lalu.

(18) *Salju telah turun hampir setiap akhir pekan musim dingin lalu.

In the following senteces, Indonesian language does not use the word ADALAH but English uses TO $\mathrm{BE}$ as a linking verb:

*saya adalah sakit pekan lalu.

*kue itu adalah lezat

2) Past Perfect

Basically there is no difference in the function of past perfect form between Indonesian language and English. In this form, the finite form in English is HAD; its equivalent in Indonesian language is TELAH. But not all sentences use TELAH.
When the subordinator SEBELUM is used, as seen in sentences number 1a, Indonesian language sentences uses the verb form [TELAH + VERB] in the main clause to accomplish the function of the past perfect form in English. This is similar to English. However, if the subordinator SETELAH is used in the subordinate clause, as in sentence $1 \mathrm{~b}$, only the verb is used in it to indicate the first completed action before another action in the past. This is different from English, in Indonesian language, this is a wrong structure:

(19) * Setelah para tamu telah pergi, saya pergi tidur.

3) Past Progressive

For the past continous form, Indonesian language uses SEDANG. Whether the progressive action is at present or in the past, Indonesian language uses SEDANG. In Indonesian language, the form [TELAH SEDANG + VERB] is never used. These are wrong structures:

(20) * Dia telah sedang berjalan kaki

ke sekolah pukul 08.30 pagi ini.

(21) *Karen telah sedang mencuci rambutnya ketika telepon berdering

(22) *Keika Alec telah sedang melakukan perjalanan di Eropa, rumahnya di cat.

The finite form in past continous form is WAS or WERE in English. There are no equivalents in Indonesian language. As it was noted earlier, SEDANG can be used both for the present and past progressive. Only through the time expression can one distinguishes whether something is ongoing activity in the present or it is in the past.

In sentences 1a, the time expressions which is used is THIS MORNING in the context of the past. In sentences $2 \mathrm{a}-2 \mathrm{~b}$ although there are no time expressions, the words WHEN and 
WHILE, both translated as KETIKA in Indonesian language, also can be signed to show that the actions were happening in the past in the context used by the speaker.

From all descriptions above, the researcher maintains that is no past continous form of the verb in Indonesian language. The function of the past continous form in English are accomplished by the verb form [SEDANG + VERB] is formed in the basis of the continous aspect of the verb, not in the tense.

4) Past perfect progressive
The finite form in the past perfect continous form of English is HAS or HAVE which has its equivalent in Indonesian language TELAH. In this form, English combines present form and two aspects (perfect and continous). In Indonesian language, this is not a case. Indonesian language only uses TELAH. The following sentences are unacceptable:

(23) * Dia telah sedang berjalan kaki

ke sekolah sebelum ayahnya membelikannya sebuah sepeda.

(24)* Carol telah sedang bekerja sangat keras, sehingga dokternya memberitahu dia untuk berlibur.

The aspect of Future Tense can be seen from the table below.

\begin{tabular}{|c|c|c|c|}
\hline \multicolumn{4}{|c|}{ Aspect (tense) } \\
\hline Future simple & Future Perfect & $\begin{array}{c}\text { Future } \\
\text { progressive }\end{array}$ & $\begin{array}{l}\text { Future perfect } \\
\text { progressive }\end{array}$ \\
\hline "tensed" & $\begin{array}{l}\text { "tensed" have }+ \\
\text { past participle }\end{array}$ & $\begin{array}{l}\text { "tensed" be }+ \\
\text { present participle }\end{array}$ & $\begin{array}{l}\text { "tensed" have }+ \\
\text { past participle or be } \\
\text { (been) + present } \\
\text { participle }\end{array}$ \\
\hline $\begin{array}{l}\text { 1. An action } \\
\text { that will happen } \\
\text { at a definite } \\
\text { future time }\end{array}$ & $\begin{array}{l}\text { 1. A future } \\
\text { action that will } \\
\text { completed } \\
\text { before a }\end{array}$ & $\begin{array}{l}\text { 1. An } \\
\text { action that will } \\
\text { be in progress } \\
\text { at a definite }\end{array}$ & $\begin{array}{l}\text { 1. Durative } \\
\text { or habitual } \\
\text { action that is } \\
\text { taking place in }\end{array}$ \\
\hline $\begin{array}{lrr}\text { a. } & \text { He } & \text { will } \\
\text { walk to } & \text { school }\end{array}$ & $\begin{array}{l}\text { specific future } \\
\text { time. }\end{array}$ & $\begin{array}{l}\text { time in the } \\
\text { near future }\end{array}$ & $\begin{array}{l}\text { the present and } \\
\text { that }\end{array}$ \\
\hline $\begin{array}{l}\text { tomorrow } \\
\text { (sample 1: 64) }\end{array}$ & & $\begin{array}{cc}\text { a. } & \mathrm{He} \text { will } \\
\text { be } & \text { walking }\end{array}$ & $\begin{array}{ll}\text { continue into } \\
\text { the future upn }\end{array}$ \\
\hline $\begin{array}{l}\text { Dia akan berjalan } \\
\text { kaki ke sekolah } \\
\text { besok. }\end{array}$ & $\begin{array}{l}\text { all this typing } \\
\text { by } 5 \mathrm{pm} \text {. } \\
\text { Saya akan }\end{array}$ & $\begin{array}{l}\text { to school at } 8 \\
\text { am tomorrow } \\
\text { (sample } 1 \text { : }\end{array}$ & $\begin{array}{l}\text { until or through } \\
\text { a specific future } \\
\text { time. }\end{array}$ \\
\hline $\begin{array}{l}2 . \quad \mathrm{A} \\
\text { habitual action } \\
\text { in the future }\end{array}$ & $\begin{array}{l}\text { menyelesaika } \\
\boldsymbol{n} \text { pengetikan } \\
\text { ini pukul } 5\end{array}$ & $\begin{array}{l}\text { 64) } \\
\text { Dia } \quad \text { akan } \\
\text { berjalan }\end{array}$ & $\begin{array}{l}\text { a. } \mathrm{He} \text { will } \\
\text { have } \\
\text { been } \\
\text { riding his bike }\end{array}$ \\
\hline $\begin{array}{l}\text { a. Joel will } \\
\text { take the bus to } \\
\text { work next year. } \\
\text { (sample } 1: 64)\end{array}$ & sore. & $\begin{array}{l}\text { ke sekolah } \\
\text { pada pukul } 8 \\
\text { pagi besok } \\
\text { 2. The }\end{array}$ & $\begin{array}{l}\text { to school for } \\
\text { two years by the } \\
\text { time } \\
\text { graduates in }\end{array}$ \\
\hline $\begin{array}{c}\text { Joel akan } \\
\text { menggunakan }\end{array}$ & & $\begin{array}{l}\text { duration of } \\
\text { some definite }\end{array}$ & $\begin{array}{l}\text { June. (sample 1: } \\
66 \text { ) }\end{array}$ \\
\hline $\begin{array}{ll}\text { bus } & \text { untuk } \\
\text { bekerja } & \text { tahun }\end{array}$ & & $\begin{array}{l}\text { action that will } \\
\text { happen in the }\end{array}$ & $\begin{array}{c}\text { Dia telah } \\
\text { mengendarai }\end{array}$ \\
\hline
\end{tabular}




\begin{tabular}{|c|c|c|}
\hline $\begin{array}{l}\text { depan. } \\
\text { b. I'm sure } \\
\text { everything will } \\
\text { be fine. } \\
\text { (sample 1: 64) } \\
\text { Saya yakin } \\
\text { semuanya akan } \\
\text { baik-baik saja. } \\
\text { 3. A situation } \\
\text { referring to } \\
\text { present and } \\
\text { future time } \\
\text { a. Nora will } \\
\text { live in Caracas } \\
\text { until she finishes } \\
\text { school. (sample } \\
\text { 1: 64) } \\
\text { Nora akan tinggal } \\
\text { di Caracas } \\
\text { sampai dia lulus } \\
\text { sekolah. } \\
\text { 4. In main } \\
\text { clause of future } \\
\text { coditionals } \\
\text { a. If you go, } \\
\text { you will be } \\
\text { sorry. (sample } 1: \\
\text { 64) kamu akan } \\
\text { Jika kamu pergi, } \\
\text { kamu anyesal. } \\
\text { menan }\end{array}$ & $\begin{array}{l}\text { future. } \\
\text { a. Mavis } \\
\text { will be } \\
\text { working on } \\
\text { her thesis for } \\
\text { the next ten } \\
\text { years. (sample } \\
\text { 1: 64) } \\
\text { Mavis akan } \\
\text { mengerjakan } \\
\text { tesis nya } \\
\text { untuk } \\
\text { sepuluh } \\
\text { tahun } \\
\text { depan. ke }\end{array}$ & \begin{tabular}{l}
\multicolumn{3}{c}{ sepedanya ke } \\
sekolah selama \\
dua tahun saat \\
dia lulus bulan \\
Juni. \\
b. On \\
christmast eve \\
our family will \\
have been \\
living $r$ \\
Chicago for 20 \\
years. (sample \\
1: 66) rada \\
Pada perayaan \\
natal keluarga \\
kami telah \\
tinggal r di \\
Chicago selama \\
20 tahun.
\end{tabular} \\
\hline
\end{tabular}

Table 4.3. Future Tense

Sample 1. The Gramar Book An ESL / EFL Teacher's Course; Sample 2. Oxford Practice Grammar

From the table 3 above, it can be described as the following.

1) Future simple

As seen in the sentences above, in Indonesian language can use or omit AKAN as long as there is a future time expression like tomorrow (besok), next month (bulan depan), etc. in the sentence. For instance, the sentence in number 1 can also be written as following:

(25) He will walk to school tomorrow.

(26) Dia berjalan kaki ke sekolah besok.

(27) So, AKAN here is optional.

The simple future form of the verb in English [WILL/SHALL + BASE 
FORM of the verb] is equivalent to either one of two forms in Indonesian language: AKAN and the verb or the verb with FUTURE TIME EXPRESSION. In English, WILL/SHALL is finite verb form because they can be converted into WOULD and SHOULD. In Indonesian language, the word AKAN does not change form at all. So, it is a nonfinite verb.

2) Future perfect

The finite verb in the future perfect form in English is WILL or SHALL, which has an equivalent in Indonesian language: AKAN. In this form, both Indonesian language and English have the combination of perfect aspect and future in one form. Indonesian language, in this case, uses SELESAI or MENYELESAIKAN with AKAN, not TELAH. Below are wrong structures:

(28) *Saya akan telah menyelesaikan pengetikan ini pukul 5 sore.

3) Future progressive

English has a continous aspect in the future form while this is not the case in Indonesian language. Indonesian language uses only the word AKAN. There is no combination of AKAN+SEDANG.

The sentences below are wrong sentences corresponding to sentences 1a-2a:

(29) * Dia akan sedang berjalan kaki

ke sekolah pada pukul 8 pagi besok. (30) * Mavis akan sedang mengerjakan tesis nya untuk sepuluh tahun ke depan.
4) Future perfect progressive

In the future perfect continous form, the marker that is used in Indonesian language is SUDAH or TELAH, not AKAN, but the meaning of the sentence still refers to the future. So, between English and Indonesian language there is no difference in function, but the form. In this case, the equivalent in Indonesian language of the finite verb SHALL or WILL, in English is SUDAH or TELAH. Indonesian language does not have the combination of future form and aspects (perfect and progressive) while English does. AKAN and SUDAH or TELAH are not used together as seen in following incorrect sentences in Indonesian language:

(31) *Dia telah akan mengendarai sepedanya ke sekolah selama dua tahun saat dia lulus bulan Juni.

(32) *Pada perayaan natal keluarga kami telah akan tinggal di Chicago selama 20 tahun.

TELAH here refers to the completion of an action. The future time is in the context used by the speaker. The adverb SELAMA (FOR) shows the duration of an event.

\section{CONCLUSION}

In contrastive analysis, one compares and contrasts different language. This comparison and contrast can be done because every language has its own individuality, that is, there is no language which is exactly the same with another language. What is meant by comparison and contrast is that one seek the similarities and differences between one language and the other language. 
In this research, the researcher presents a comparison and contrast between English and Indonesian language in terms of finite verb form, tense and aspect. In connection with this problem, the researcher sought the answers to the questions about the finite verb form in English and its equivalent in Indonesian language and whether there are any similarities and differences between English

\section{BIBLIOGRAPHY}

Aarts, F \& Aarts, J. 1988. English Syntatic

Structure: Functions and

Categories in Sentence Analysis.

New York: Prentice Hall

International (UK) Ltd.

Biber, Douglas \& Conrad \& Leech. 2002.

Longman Student Grammar of Spoken and Written English.

London: Longman Group Ltd.

Boer, John J.D. 1982. Basic Language

Messages and Meaning. New York:

Harper and Row Publisher

Chaer, A. 1994. Linguistik Umum. Jakarta:

PT Rineka Cipta.

Curme, G. O. 1935. Parts of speech and accidence. Boston: D.C. Heath

Company

Delahunty, Gerald. P \& James J. Garvey. 2010. The English Language from

Sound to Sense. Colorado: The

WAC Clearinghouse

James, Carl. 1980. Contrastive

Analysis. London: Longman

Group Ltd. and Indonesian language in terms of tense and aspect.

Tense here means time, and aspect means whether an action is in progress or completed action. Function describes the relation between an action or event with the tense and aspect which influences the use of a verb in different forms. A verb means a word that expresses an action or state / being.

Lado, R. 1990. Linguistics across culture. Ann Arber: The University of Michigan Press.

Langacker. 1972. Fundamentals of Linguistic Analysis. New York: Harcourt Brace Jovanovich, Inc

Pak. 1979. An Axiomatic Theory of Language with Application to English. Illinois: Jupiter press

Siregar, R. 1987. Bahasa Indonesia jurnalistik. Jakarta: Pustaka Karya Grafika Utama.

Shertzer, Margaret. 1986. The Elements of Grammar. London: Collier Macmilllan Publishers

Tulloch, Graham. 1990. English Grammar A Short Guide. Australia: Flinders Press 